\title{
Kasih Sejati: Memahami Misi Secara Teks, Konteks, dan Komunitas Berdasarkan Yohanes 17:18 Pada PTT/AK
}

\author{
Sensius Amon Karlau \\ STT Arastamar Wamena \\ saranapak@yahoo.co.id
}

\begin{abstract}
:
The existence of God is in essence impossible to shift, but, in fact seems to experience a shift that appears in human efforts to respond to the mission call. Efforts to "narrow" the meaning, purpose and impact of understanding the "true love and mission" for His people here are in contrast to God's love that cannot be separated from His essence. God himself wants His love to be part of His ransom people, so this is where "mission" becomes the logical implication of God's existence as a mission initiator that has been, is being, and continues to be done through His chosen people in every age in (community). The author used qualitative method with text and language analysis approaches. Based on research results in the "text" it can be understood that God's love enables Him to send His only begotten Son to fulfill His mission. Then in His grace; The Son continues the Father's mandate to disciples to become a "community" sharing the love of God the Father. This task is then passed on to the present generation specifically for graduates of Theological/Christian Religious College.
\end{abstract}

Key Words: True Love, Text, Context, Community

\begin{abstract}
Abstrak:
Eksistensi Allah pada hakikatnya tidak mungkin bergeser, namun, pada kenyataannya terkesan mengalami pergeseran yang nampak dalam upaya manusia meresponi panggilan missions. Upaya "menyempitkan" makna, tujuan dan dampak dari pemahaman akan "kasih sejati dan misi" bagi umat-Nya disini bertolak belakang dengan kasih Allah yang tidak dapat dipisahkan dengan hakikat-Nya. Allah sendiri menginginkan agar kasih-Nya menjadi bagian dari umat tebusan-Nya", maka disinilah hal "misi" menjadi implikasi logis dari eksistensi Allah sebagai Inisiator misi yang telah, sedang, dan terus dikerjakan melalui orang-orang pilihan-Nya pada setiap zamannya dalam (komunitas). Penulis menggunakan metode kualitatif (Qualitative Research) dengan pendekatatan analisis teks dan Bahasa. Berdasarkan hasil kajian secara "teks" dapat dipahami bahwa kasih Allah memungkinkan Dia mengutus Anak-Nya yang tunggal untuk menggenapi misi-Nya. Kemudian dalam anugerah-Nya; Sang Anak meneruskan mandat Allah Bapa itu kepada para murid untuk menjadi satu "komunitas" pembagi kasih Allah Bapa. Tugas inilah yang kemudian diteruskan pada generasi masa kini secara khusus bagi lulusan Perguruan Tinggi Teologi / Agama Kristen.
\end{abstract}

Kata Kunci: Kasih Sejati, Teks, Konteks, Komunitas.

\section{Pendahuluan}

Secara prinsip, landasan dari tema ini menarik untuk dimaknai karena menyinggung mengenai kasih sejati Allah Bapa ketika mengutus Anak-Nya yang tunggal yakni Yesus Kristus, dan kemudian mengutus para murid-Nya pada masa itu sangat berelasi dengan aspek teologis dan misi. Maka dalam kajian ini, penulis akan membahas tema ini dengan "memberangkatnya" secara teologi misi, dengan menjadikan teks 
Yohanes 17:18 sebagai lokus dari kajian ini sebagai upaya yang baik guna memaknai hal mengenai misi yang sangat kompleks namun menarik untuk dibahas.

Disadari akan realitas kekinian yang sangat mengalami pergeseran dalam segala bidang, yang tidak dapat dibendung membuat manusia semakin sulit mewujudkan summum bonum, yang pada saat ini banyak didiskusikan dalam kelas-kelas ilmiah dan juga dalam implikasinya secara praksis dalam kehidupan sehari-hari. summum bonum merupakan kebaikan tertinggi bagi umat Allah dan segenap ciptaan-Nya yang dapat terwujud ketika misi atau rahmat syalom dari Allah yang utus beroperasi dengan dinamika yang holistik dalam mewujudkan syalom Allah dalam segala spek dan bidang kehidupan (Tomatala, 2005).

Dalam konteks kekristenan, hal ini tentunya tidak terlepas dari berbagai gelombang pemikiran teologi dan misi serta perkembangan peradaban dunia yang sangat kompleks dimana kekristenan ikut ber-andil di dalamnya. Tuntutan akan sikap yang kritis dari seorang akademisi yang eksis dalam sebuah komunitas dan menghendaki adanya keseimbangan atau kesinambungan mengenai teori dan praktek dalam lokus teologi dan misi sangat penting. Dalam konteks pengajaran Kristen, banyaknya literatur mengenai misi yang memiliki keterkaitan erat dengan kasih sejati Allah berdasarkan anugerah-Nya yang tak terhingga, rupanya tidak selalu direspons dengan sikap aktif oleh semua orang Kristen yang memahami aspek teologi dan misi karena menganggap bahwa sikap pasif pun cukup untuk memberi jawab bagi panggilan imannya. Hal ini terlihat dari banyaknya lulusan Sekolah Tinggi Teologi dan Agama Kristen (PTT/AK) yang saat ini cukup banyak memiliki lulusan yang tersebar di seluruh Indonesia dan berkecimpung dalam segala bidang. Namun kontribusi misi masih dianggap belum signifikan. Data Pangkalan data (PD-DIKTI) saat ini terdapat 382 PTT/AK dengan rincian 7 PTT/AK Negeri dan 375 PTAK Swasta dengan jumlah Prodi tidak kurang dari 1.500 apabila ditambah dengan prodi-prodi keagamaan Kristen yang berada di Lembaga Pendidikan Tinggi yang bukan di bawah Binaan Direktorat Jenderal Bimbingan Masyarakat Kristen Kementerian Agama RI (lihat httpp://forlap. ristekdikti.go.id/perguruantinggi)

Keseimbangan atau kesinambungan mengenai teologi dan misi selalu berkembang dalam konteks ilmiasitas. Hal ini tidak dapat dipisahkan dengan berbagai refleksi secara ilmiah, yang yang selalu diupayakan agar be-relefansi dengan konteks sebagai aktualisasi sikap iman kristiani seseorang. Dan hal ini, tidak terlepas dari keinginan yang teguh dalam mengejawantahkan pemahaman yang dimiliki mengenai kasih sejati Allah, yang nampak dalam aspek misi itu sendiri. Wright (Wright, 2013) dalam pendahuluan bukunya yang berjudul "Misi Umat Allah" mengemukakan; Kelihatannya, teologi hanya melulu berkutat tentang Allah. Teologi berkisaran pada apa saja yang dipikirkan dan dituliskan sejumlah orang (yang kebanyakan sudah almarhum) tentang Allah, sifat dan tindakan-Nya, relasi-Nya dengan dunia, dengan masyarakat 
manusia, keterlibatan Allah di masa dulu, masa sekarang, dan masa mendatang, dan sejenisnya. Dalam kontras yang menyenangkan, misi berkutat tentang kita, manusia yang hidup, apa yang kita (atau paling sedikit sebagian dari kita) yakni harus kita lakukan di dunia supaya bisa sedikit menolong Allah. Misi kelihatannya berkutat tentang, menolong Allah mengatasi berbagai rintangan budaya aneh dan tempat-tempat jauh yang kelihatannya sulit ia terobos.

Pernyataan Wright memiliki kesan "menggelitik" karena ia menginginkan agar teologi semestinya tidak boleh berbicara hanya mengenai Allah dengan eksistensi, sifat dan karya-Nya yang tidak bersentuhan dengan hal misi. Namun secara tegas perlu juga menampakan kasih sejati dari Allah yang terlihat dalam misi yang berdampak pada sumum bonnum itu sendiri. Teologi tidak cukup jikalau hanya menjadi konsumsi teori yang bersifat history semata. Sebabnya, teori-teori mengenai teologi dan misi Allah sebaiknya direlasikan dengan fakta-fakta di lapangan pada masa kini secara real. Jika hal ini dilakukan maka tentunya akan memperlihatkan rumusan-rumusan aplikatif mengenai cinta kasih Allah yang sejati. Benarlah apa yang dikatakan oleh Calvin yang dikutip Wright ketika mengomentari Kejadian 18:19 dan menegaskan "Allah tidak hanya bermaksud menceriterakan maksud dan rencana-Nya hanya kepada Abraham saja, melainkan bermaksud menceriterakan kasih dan maksud-Nya bagi seluruh keturunan Abraham di segala zaman untuk mengetahui kehendak-Nya dan tidak hanya berhenti. Namun apa yang diketahui wajib disaksikan bagi generasi selanjutnya sehingga pada gilirannya mereka bisa meneruskan apa yang mereka terima bagi keturunan mereka...dengan cara inilah kita mesti menyebarluaskan kebenaran Allah. Sebab, Ia tidak hanya diberikan sebatas untuk kesenangan pribadi kita; kita harus saling menguatkan sesuai panggilan kita" (Calvin, 2001).

Persoalan penting yang saat ini terjadi yaitu bagaimana pelaksanaan misi, sebagai bagian dari upaya mengejawantahkan kasih sejati dari Allah dapat memberikan solusi penting bagi peradaban manusia secara universal dan khususnya bagi kekristenan itu sendiri. Sebab diketahui bahwa upaya memahami "misi" pun saat ini terus mengalami perkembangan. Atau dalam terminology yang digunakan oleh Lumintang yaitu "pergeseran". Lumintang menegsakan dalam pendahuluan bukunya bahwa "misi Allah tidak pernah berubah, karena misi-Nya berangkat dari hakekat Allah yang tidak dapat berubah. Ketidakberubahan misi Allah termanifestasi dalam kuasa-Nya yang telah, sedang dan terus mengubah dunia. Hanya "yang" tidak berubah yang memiliki kuasa mengubah. Sedangkan yang diubah pasti berubah dan tidak memiliki kuasa mengubah. Misi Allah tidak berubah, namun misi Allah telah [terus] berubah dalam pemahaman gereja. Dan patut disyukuri bahwa perrubahan pemahaman Gereja mengenai misi adalah perubahan ke arah kemajuan. Namu pada sisi lain, patut untuk dicermati dan digumuli secara serius adalah perubahan pemahaman misi yang dibarengi dengan pergeseran 
hakekat gereja dan misi itu sendiri. Perubahan ini adalah perubahan kearah kemerosotan atau penyimpangan (Lumintang, 2009).

Penyimpangan yang dimaksudkan (Lumintang, 2009), yaitu sebagai akibat dari upaya "mendaratkan" teks (Alkitab) dengan "konteks" (sosial, budaya, politik dll) yang telah dikemukakan sebelumnya, bahwa misi pada era moden ini, sebagaimana dipahami bahwa selalu berangkat dari landasan teologis yang mutlak, yang mana tidak dapat dipisahkan dengan "teks" (Alkitab). Namun para ahli misi mengemukakan bahwa misi sesungguhnya juga tidak boleh dilepaskan dengan hal "konteks" (budaya, sosial, politik dll) dan "komunitas". Sebagai penyebab persoalan misiologi masa kini, yaitu persoalan mempertahankan secara integratif antara wilayah teks, konteks dan komunitas. pada umumnya persoalan misi masa kini adalah berkenaan dengan penenkanan yang berlebihan kepada salah satu wilayah studi, sehingga pengertian misi diformulasi dalam pengertian yang sempit dan terus berubah (Lumintang, 2009). Disinilah selalu muncul formulasi dan pemahaman baru yang penting ketika berbicara mengenai pelaksanaan dan pemaknaan misi.

Pada tataran "teks" yang diklaim oleh kaum "Injili" sebagai sebuah kebenaran dalam bermisi ternyata dibantah oleh kaum "Oikumenikal" yang selalu menekankan tentang "konteks" yang dalam pelaksanaannya kadang-kadang bertolak belakang dengan "teks". Maka belakangan, muncul lagi hal lain yang tidak dapat dipisahkan dengan "misi yaitu "komunitas". Maka melalui kajian ini, penulis hendak menekankannya secara seimbang agar menghindari upaya "penyempitan" dari memahami misi yang holistik serta relevan pada masa kini dimana penekanan "teks" oleh kaum Injili dianggap oleh kaum Oikumenikal tidak relevan dengan kondisi dan peradaban dunia modern ini, yang menganggap bahwa "konteks" sebaiknya lebih diutamakan karena sisi "kemusiaan" melampaui sekat-sekat keagamaan yang dapat membatasi efektifitas pelaksanaan misi.

Rumuan masalah atau pertanyaan dalam penelitian ini adalah bagaimana memahami kasih sejati Allah berdasarkan Yohanes 17:18 yang terimplikasi secara esensial dengan misi-Nya melalui "perutusan" Anak-Nya untuk menjadi jalan tengah dalam membangun diskusi tentang teks, konteks dan komunitas yang dipahami dengan baik mampu menghidupkan kembali berbagai kalangan, lembaga misi dan khsusnya lembaga pendidikan teologi (PTT/AK)? Tujuan dari penelitian ini untuk mengkaji dan memahami kasih sejati Allah berdasarkan Yohanes 17:18 yang terimplikasi secara esensial dengan misi-Nya, yang dipahami dalam terminologi setiap teks, konteks" dan komunitas bagi setiap lulusan atau alumni Sekolah Tinggi Teologi (STT) atau Sekolah Tinggi Agama Kristen (STAK), sebagai bagian dari "pelaksana misi".

\section{.Metode}

Untuk menghasilkan tulisan ini, penulis melakukan penelitian kualitatif (Qualitative Research). Menurut Timotius (2017) dan Sugiyono (2017) bahwa metode 
kualitatif digunakan untuk mendapatkan data yang mendalam, suatu data yang mengandung makna berdasarkan library research yang berusaha menganalisis. Terkait dengan metode analisis, Bugin (Hartati, 2017) mengemukakan bahwa terdapat tiga kelompok besar metode analisis data kualitatif yang dimana salah satunya adalah kelompok metode analisis teks dan bahasa. Selanjutnya, metode deskriptif digunakan untuk melukiskan secara sistematis yang pada hakekatnya adalah mencari teori melalui analisa teks. Creswell (2016) mengatakan bahwa rancangan ini terutama terkait dengan pengumpulan data, analisis data, dan laporan penelitian dimana data disini dapat berupa gambar maupun teks yang dieksegesis. Dalam bahasa Yunani, kata eksegesis berasal dari kata exagw; exsagō yang dapat diterjemahkan "lead out, bring out, dan memiliki pengetian "membawa atau menuntun keluar" (Balz \& Schneider, 1994a). Maksudnya berusaha menemukan dan membawa keluar maksud para penulis, pembaca, dan pendengar Alkitab dalam konteks bahasa, sejarah, budaya, geogerafi dan lainnya secara asali melalui proses analisis (analisa teks) yang mendalam (Colins, 1996). Eksegesis ditujukan untuk menggali makna teks, sebagaimana dahulu dimaksudkan oleh penulis teks itu dengan presuposisi penting bahwa "Alkitab berkuasa menjelaskan dirinya" (Ferguson, 1986). Jadi tafsiran didasarkan pada studi bahasa asli, arkeologi, antropologi dan belakangan ini juga sosiologi.

Kata exagw; exsagō memiliki kaitan dengan kata exegeomai; exsegeomai artinya "menceriterakan" atau "menerangkan" serta "menyatakan" dan "memperlihatkan". (Yoh. 1:18, Kis. 10:8, 15:12,14, 21:19). Akar kata Yunani ini mempunyai arti “membawa keluar dari”. Maka ketika kata exagw; exsagō digunakan atau dijadikan sebagai cara mendekati, memahami suatu teks atau tulisan PB, maka kata ini dapat berarti "tidak memasukan" gagasan, ide, atau pemahaman atau pemaknaan pribadi pembaca dan pendengar ke dalam tulisan sebagaimana pada teks tersebut. Perlu ditegaskan lagi bahwa jika kata exagw; exsagō atau eksegese diterapkan pada sebuah teks tertentu, maka kata yang berarti kegiatan untuk membawa keluar, dalam arti menggali dan mendeskripsikan sebuah makna teks tersebut secara transkripsi', gramatikal', leksikal', serta sintaksis. Pohan dan Setiawidi (2015) mengatakan: secara harfiah, transkripsi berarti pengubahan atau pengalihan tulisan. Dalam hal ini, pengalihan dari "tulisan asli" ke tulisan lain, misalnya: Dari tulisan Ibrani atau Yunani ke tulisan Latin, dan sebaliknya. Transkripsi juga sering dilakukan karena alasan praktis yang lain, yaitu untuk mempercepat proses penulisan. Ada dua jenis transkripsi, Yaitu: transkripsi yang didasarkan pada transliterasi (pengalihan huruf) dan transkripsi yang didasarkan pada bunyi pengucapan. 1. Transkripsi yang didasarkan pada transliterasi boleh dikatakan lebih bersifat akademis. Setiap kata diubah secara teliti berdasarkan transliterasi dari setiap huruf. 2. Sedangkan transkripsi yang didasarkan pada bunyi pengucapan boleh dikatakan lebih bersifat praktis. 
Setiap kata ditranskripsikan sesuai dengan bunyi pengicapannya; sebagaimana kata itu diucapkan, begitulah transkripsinya ditulis.

Yuwono (2005) mengatakan bahwa gramatikal yaitu keadaan unsur-unsur bahasa yang saling merujuk dan berkaitan secara semantik. Dengan gramatika, sebuah wacana menjadi padu: setiap bagian pembentuk wacana mengikat bagian yang lain secara mesra dan padu. Kemudian, Yuwono mengemukakan pula bahwa gramatikal juga adalah hubungan semantik antarunsur yang dimarkahi alat gramatikal atau alat bahasa yang digunakan dalam kaitannya dengan tata bahasa. Gramatikal dapat berwujud referensi atau pengacauan, substitusi atau penyulihan, ellipsis atau pelesapan, dan konjungsi atau penggabungan. Kemudian, secara leksikal artinya "hubungan semantik" antarunsur pembentuk wacana dengan memanfaatkan unsur leksikal atau 'kata'. leksikal dapat diwujudkan dengan reiterasi dan kolokasi. Sedangkan sintaksis merupakan bagian dari subsistem tata bahasa atau gramatika. Rangkaian kata yang mematuhi kaidah sintaksis disebut apik, atau gramatikal.

Konkretnya yaitu upaya menafsirkan dan menemukan makna sebuah teks atau tulisan dalam bahasa tertentu dengan tidak bermaksud memasukan ide, konsep, atau gagasan egsegator atau orang yang melakukan eksegese melainkan bermaksud membawa keluar setiap makna sebuah teks dan mengimplikasikan atau mengaplikasikannya sesuai dengan konteks kekinian bagi upaya memberi makna penting bagi kalimat yang tertera dalam teks Injil Yohanes pasal 17:18 sebagaimana dijadikan sebagai rujukan tema pada momen ini.

\section{Hasil dan Pembahasan}

\section{Misi Berdasarkan "Teks" Dalam 17:18}

Teks Alkitab dalam Injil Yohanes 17:18 yang merupakan bagian integral dari pasal-pasal sebelumnya dan pasal setelahnya bahkan seluruh Injil Yohanes menjadi rujukan penting dalam penelitian ini. Namun, dalam kajian ini membatasi sebatas pada kata-kata, frasa, klausa dan kalimat sebagaimana dikatakan :

Sama seperti Engkau telah mengutus Aku ke dalam dunia, demikian pula Aku telah mengutus mereka ke dalam dunia; (TB-LAI)

Memaknai kalimat secara konsentris sebagaimana terdeskripsi disini tidak dapat dipisahkan dengan konteks dan alur ceritera serta struktur teks dan kitab sebagaimana tergambar pada seluruh Kitab Injil Yohanes. Namun pada penelitian ini penulis memfokuskan pembahasan hanya pada aspek leksikal dan gramatikal dari pasal 17:18 pada Kitab Injil Yohanes yang penulis rajut dalam artikel ini dengan judul "Kasih Sejati: Sebagaimana Allah mengutus-Ku, Ku, utus kalian, (Memahami Misi Secara Teks, 
Konteks, dan Komunitas pada PTT/AK berdasarkan Yohanes 17:18)" yang terkait erat dengan aspek misi.

\section{Teks Yunani dan Transkripsi}

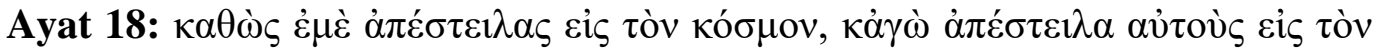

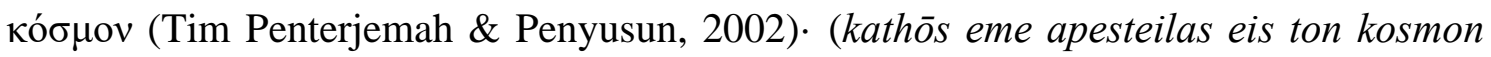
kagō apesteila autous eis tov.)

\section{Analisis Leksikal}

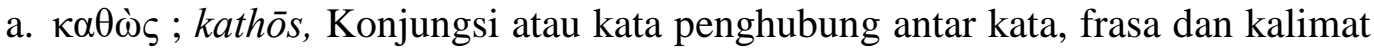
yang berasal dari kata dasar $\kappa \alpha \theta \grave{\varsigma} \varsigma$ yang dapat diterjemahkan'(Rogers Jr, L. \& Rogers III, 1998) "seperti; sesuai dengan; karena; ketika; bagaimana (Sutanto, 2004b). Kata (penghubung) yang dapat juga berfungsi sebagai kata (perbandingan) "sama seperti".

b. $\dot{\varepsilon} \mu \grave{\varepsilon} ;$ eme, adalah kata ganti orang bentuk akusativ tunggal dari kata dasar egō yang dapat diterjemahkan saya (obyek). (Rogers Jr, L. \& Rogers III, 1998; Sutanto, 2004b).

a. $\dot{\alpha} \pi \varepsilon ́ \sigma \tau \varepsilon ı \lambda \alpha \varsigma ;$ apesteilas adalah kata kerja indikativ aorist aktif orang kedua tunggal dari kata dasar apostelō' (Sutanto, 2004a) yang dapat diterjemahkan "engkau mengutus"(Sutanto, 2004b).

c. eis ; eis, kata depan atau kata perangkai dengan bentuk kasus "akusativ" yang artinya "ke dalam; menjadi; sampai kepada" (Pandensolang, 2010).

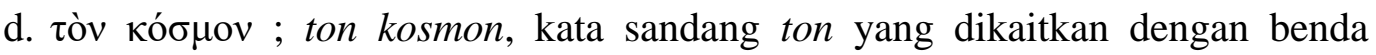
maskulin akusativ tunggal dari kata dasar kosmos. Bentuk akusativ memberikan makna bahwa kosmos di sini yaitu sebagai obyek. Kata ini diterjemahkan "cara berhias; perhiasan; dunia; jumlah besar. (kata ini digunakan dua kali dengan bentuk tata bahasa yang sama).

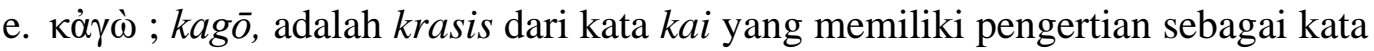
penghubung antarkata, atau antarfrasa, antarklausa dan antarkalimat yang artinya "dan; juga; bahkan; dan khususnya; memang; bahwa; yaitu; ketika; maka; adapun; demikian juga; demikian; sehingga; malah; namun; walaupun; padahal; kemudian; lalu; karena; bukan saja; tetapi juga; atau; dari” (Pandensolang, 2010) dan kata ganti orang pertama tunggal dengan bentuk kasusnya yaitu nominativ tunggal yan dapat diterjemahkan "dan saya sedang"

f. $\dot{\alpha} \pi \varepsilon ́ \sigma \tau \varepsilon ı \lambda \alpha$; Kata kerja Indikativ Aoris dari orang kedua tunggal dari kata dasar "apostello" yang dapat diterjemahkan' (Sutanto, 2004a) "mengirim" 
(Sutanto, 2004b). Dan penulis menerjemahkannya dengan "saya dulu sedang mengirim engkau"

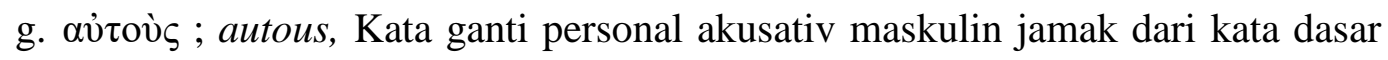
autoj yang artinya "diri”, "sendiri”, “itulah", "bahkan”, “yang sama”, "ia", "mereka" (Sutanto, 2004b).

h. eis ; eis kata depan atau kata perangkai dengan bentuk kasus "akusativ" yang artinya "ke dalam; menjadi; sampai kepada" (Pandensolang, 2010) (kata ini digunakan dua kali dengan pengertian yang sama dalam satu kalimat).

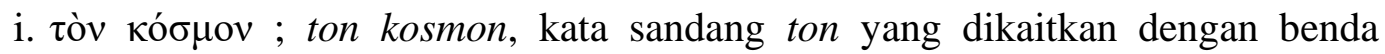
maskulin akusativ tunggal dari kata dasar kosmos. Bentuk akusativ memberikan makna bahwa kosmos di sini yaitu sebagai obyek. Kata ini diterjemahkan "cara berhias; perhiasan; dunia; jumlah besar. (sebagai obyek).

Terjemahan Literal

Sama seperti Engkau [Allah Bapa dulu] telah mengutus Aku ke dalam dunia ini, demikian pula sekarang Aku mengutus engkau [sendiri-sendiri] kepada mereka di dalam dunia ini (Rogers Jr, L. \& Rogers III, 1998).

Analisis Leksikal (Kata) dan Gramatika (Tata Bahasa)

Pada bagian ini, penulis hendak menyelidiki dan memaparkan semua kata, yakni; kata benda, kata, kerja, kata sifat, kata keterangan, kata ganti, kata penghubung, kata sandang, kata depan serta lainya yang terdapat dalam teks Yohanes 17:18. Penulis menganggap bahwa semua kata dalam bagian ini merupakan diksi yang penting untuk diselidiki guna "membawa keluar" makna sesungguhnya sesuai dengan maksud penulis berdasarkan teks dimaksud, sebagaimana dikatakan dalam teks Yunaninya demikian:

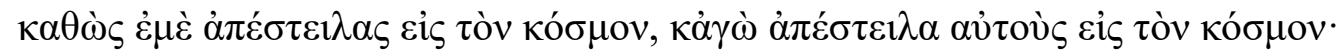

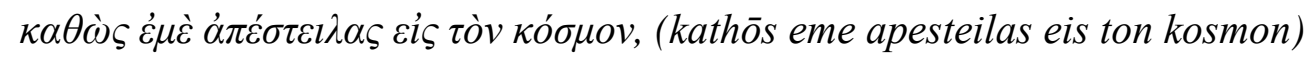

Kalimat pada ayat 18 diawali dengan klausa penting yang dalam bahasa Yunaninya

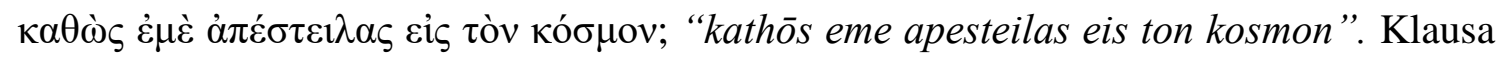
yang juga sudah tergolong kalimat ini diterjemahkan oleh (TB-LAI) "sama seperti Engkau telah mengutus Aku ke dalam dunia”. Dalam teks Yunani, kalimat ini diawali

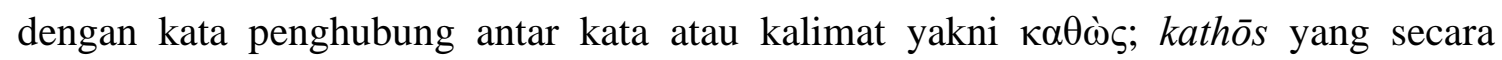
sederhana dapat diterjemahkan dengan "sama seperti". Kata ini memberikan kesan penting bahwa apa yang hendak dikemukakan merupakan bagian yang berkaitan erat dengan konteks literer sebelumnya. Guthrie menegaskan bahwa "rupanya pada pasal ini 
sesungguhnya merupakan kata-kata doa dari Yesus bagi para murid yang bersifat internal. Secara struktur, Yesus sudah lebih dahulu memberikan wejangan penting bagi para murid agar mereka memahami diri mereka sebagai pribadi-pribadi yang telah dipilih Allah untuk sebuah tugas yang mulia dalam jaminan doa-Nya yang memberi jaminan bahwa Ia melindungi mereka, having prayed to the Father to protect the disciples, Jesus declared that he had protected them (Wenham \& Carson, 2010).

Pernyataan Guthrie, yang penulis dianggap sebagai upaya merangkum keseluruhan doa Yesus ini kemudian dilanjutkan dengan sebuah kata penghubung $\kappa \alpha \theta \dot{\omega} \varsigma$, kathōs untuk menyampaikan maksud Yesus selanjutnya bagi para murid agar mereka semakin menyadari akan penyertaan Allah bagi mereka. Para murid dibuka pemahamannya oleh Yesus bahwa mereka memiliki hubungan dengan dunia dimana mereka harus bermisi meskipun dunia tidak mudah menerima mereka, bahkan memusuhi atau membenci mereka (lih. Pasal 15:19 dan 15:8). Sejalan dengan Guthrie, Ridderbos (2012) menegaskan bahwa "untuk alasan itu maka Yesus tidak hanya meminta agar Allah melindungi mereka tetapi mengenalkan sudut padang lain yang mengontrol pemikiran: "Kuduskanlah mereka dalam kebenaran" (ayat 17). Dengan demikian maka disnilah pentingnya kata $\kappa \alpha \theta \grave{\varsigma}$ dimaknai sebagai kata yang "mengajak” setiap pekerja misi untuk memahami posisi Yesus dan posisi pelaku misi sebagai penerus dari mandat misi itu sendiri.

Kata berikut yang perlu dianalisa yaitu kata $\dot{\varepsilon} \mu \grave{\varepsilon}$, eme. Kata eme dapat dipahami sebagai kata ganti orang pertama yakni "saya, atau aku” sebagai obyek. Maka disini terlihat kontinuitas dari kata $\kappa \alpha \theta \grave{c}$; kathōs (sama seperti) yang merupakan kata penghubung dimana Yesus memposisikan diri-Nya sebagai obyek tunggal yang memainkan peran penting dalam aktualisasi perintah Allah Bapa. Mengomentari bagian ini, Keener (2003) sangat benar ketika menegaskan bahwa hanya Yesus sebagai satusatunya utusan Allah Bapa dalam pemahaman [missio Dei] yang kemudian berperan sebagai penerus mandat itu [mission Kristi] bagi para murid-Nya sebelum terangkat ke surga. Rupanya, Yesus mengajak para murid untuk "memahami posisi Yesus" agar dapat memahami kasih Allah Bapa yang sungguh besar, dimana Ia ingin agar kasih-Nya menjadi efektif bagi umat tebusan-Nya di dalam atau melalui diri Yesus yang saat itu sedang berbicara dengan para murid. Walaupun dipahami bahwa posisi "teks", (17:18) pada konteks Kitab Injil Yohanes memberikan gambaran bahwa finalitas karya Yesus di bumi masih ada, dan belum digenapi sepenuhnya. Yaitu, kematian, kebangkitan dan kenaikan-Nya yang akan dinyatakan pada fase selanjutnya pada pasal-pasal kemudian. Namun, hal ini penting dilakukan Yesus karena Dia menginginkan agar para murid, sedikit-demi sedikit mulai "terbuka" pemahamaan mengenai tabir penyataan dan karya Yesus di bumi. 
Kemudian kata ả $\pi \varepsilon ́ \sigma \tau \varepsilon \imath \lambda \alpha \varsigma$, apesteilas yang memiliki pengertian engkau dulu sedang mengutus. Menarik karena secara leksikal sintakstikal kata $\alpha \operatorname{s} \delta \tau \varepsilon \iota \lambda \alpha \varsigma$, apesteilas

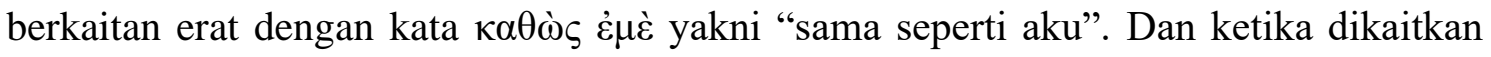
dengan kata $\dot{\alpha} \pi \varepsilon ́ \sigma \tau \varepsilon ı \lambda \alpha \varsigma$ engkau [dulu telah mengutus], maka dapat dimengerti bahwa Yesus menjadikan para murid-Nya sebagai obyek pembagi kasih Allah Bapa, sebagaimana Allah Bapa juga menjadikan Yesus sebagai "obyek" pembagi kasih-nya agar dapat meneruskan kasih yang bersumber dari Allah Bapa bagi orang yang dipilihNya. Maka secara teks, dapat dipahami bahwa 'pelaku misi' selalu berperan sebagai subyek, sebagaimana posisi Yesus dengan para murid. Hal ini terlihat dari posisi Yesus saat berbicara dengan para murid-Nya dimana Ia memposisikan diri-Nya sebagai obyek dari Allah, yang kemudian akan berdiri pada posisi subyek bagi murid-Nya ketika mereka berdiri sebagai obyek atau 'pelaku misi'.

Makna dari "subyek" di sini perlu dipahami dengan baik bahwa para murid bukan "sumber atau pemilik" kasih sejati. Melaiankan sebagai alat atau sarana "pembagi" kasih sejati yang bersumber dari Allah Bapa. Sebagai dosen, sebagai pelayan, ataupun pemberita Injil, seseorang perlu memahami bahwa diri-Nya adalah sebagai alat atau sarana untuk meneruskan kasih sejati Allah agar dapat dinikmati oleh orang lain. Dalam segala keterbatasan dan kondisi, tentunya tidak mudah menjadi penerus kasih sejati.

Pertanyaan yang muncul adalah, jika Allah berposisi sebagai subyek utama atau aktor utama dari mandat misi. Dan Yesus sebagai obyek yang [sedang] berperan sebagai Subyek bagi para murid sebagai obyek, lalu kemudian para murid akan berdiri juga sebagai subyek misi bagi penerus mandat misi, maka kemanakah, atau dimanakah

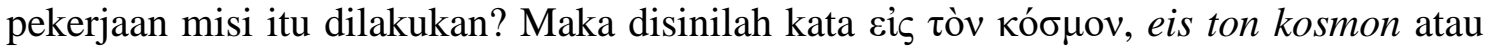
"ke dalam dunia" menjadi konteks yang di dalamnya "para pemain misi memainkan aksinya'.



Pada kalimat selanjutnya disini, diterjemahkan "demikian pula Aku telah mengutus mereka ke dalam dunia" (TB-LAI). Kata pertama dalam kalimat ini yaitu кảyò. Kata ini diterjemahkan "demikian pula" untuk menjadi penghubung atau menjajadi kata yang memberi kesan "melanjutkan" kalimat sebelumnya. Menarik, karena kata kảyò juga didalamnya tersempul kata ganti orang pertama tunggal yang berposisi sebagai subyek (nominativ) dari kata egw, egō. Kata evgw, (egō) yang adalah 'pronoun personal, first person' atau 'kata ganti orang bentuk present orang pertama tunggal' yang dapat diterjemahkan "aku atau saya sendiri [sedang]"(Schafer, n.d.). Kata egw, (egō) adalah kata yang sangat sering digunakan dalam Perjanjian Baru, dan banyak digunakan. Boleh dikatakan bahwa dalam Yunani klasik, kata egw-egō mengungkapkan suatu hal berbeda atau sebuah hal yang [harus] diperhatikan jika digunakan oleh penulis untuk 
menggambarkan seseorang. Meskipun sebagai kata ganti orang, kata egw (egō) digunakan sebanyak 1.802 kali di dalam alasan dan maksud yang berbeda-beda (Balz \& Schneider, 1994b), Secara sintakstikal, kata egw, (egō) disini dapat dimaknai sebagai penunjuk kepada "Sang Subyek yakni Yesus" yang penting bagi para murid karena Dia sendiri yang memberikan jaminan penyertaan bagi setiap pelaku "misi". Dan, penting juga untuk memberikan penegasan bagi pembaca atau pendengar serta umat Kristiani pada abad mula-mula sebagaimana diketahui tentang tekanan psikologis dan fisik yang dapat saja membuat mereka merasa ciut jika tidak ada jaminan dari sang egw, (egō) yang dapat diterjemahkan "saya sedang". Maka ketika ditambahkan dengan kata kai dalam pengertian sebagai penghubung maka dapatlah diterjemahkan "demikian pula sekarang Aku". Kata saya, atau aku disini menunjuk kepada Yesus sebagai subyek atau sang pemberi mandat atau perintah pada saat mengatakan kata ini.

Kemudian, kata selanjutnya yaitu " $\alpha \dot{\tau} \varepsilon \dot{\sigma} \tau \varepsilon ı \lambda \alpha$ ”. Kata ini adalah kata kerja yang sama ketika Yesus memposisikan diri-Nya sebaga Obyek ketika menerima mandat misi dari Bapa-Nya. Dan sekarang kata yang sama digunakan Yesus bagi para murid-Nya untuk meneruskan amanat itu kepada orang lain lagi. Terjemahan "saya [dulu] sedang mengirim engkau" menarik untuk dipahami sebagai sebuah hal yang penting bagi para murid. Bahwa perintah melakukan apa yang hendak disebutkan Yesus pada kata selanjutnya bukan bersifat kolektif atau bersifat menyeluruh, melainkan kepada masingmasing pribadi. Hal ini terlihat dari bentuk kata ganti orang yang digunakan yaitu

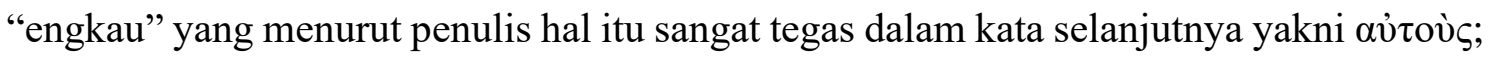
outous yang menurut penulis sebaiknya diterjemahkan "sendiri". Jadi masing-masing murid secara pribadi-pribadi menjadi penerima mandat ketika "mereka dikirim, diutus" oleh Yesus sebagai penerus mandat dari Allah Bapa. Mengomentari bagian ini, Ridderbos (2012) mengemukakan bahwa "Yesus naik banding kepada kesesuaian mandat yang telah Ia berikan kepada murid-murid-Nya dengan misi-Nya sendiri dari Bapa dan kepada fakta bahwa misi mereka didasarkan pada milik-Nya dan karena itu berfungsi untuk melanjutkan pekerjaan Bapa.

Pada akhirnya, pertanyaan yang sama sebagaimana diajukan; "kemana Yesus diutus Allah Bapa untuk untuk menjadikan kasih-Nya menjadi berdampak? Tentunya ke dalam dunia. Dan pada saat Yesus mengucapkan kalimat ini, Yesus pun hendak melakukan hal yang sama yaitu "mengirim" atau mengiutus para murid secara ( $\alpha$ vov̀s;

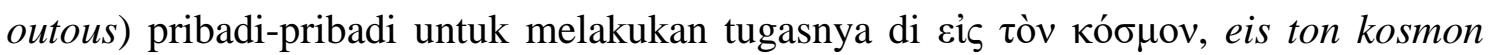
yakni "para murid dikirim ke dalam dunia sebagai sebuah konteks dimana mereka akan berperan sebagai "para pemain misi yang siap memainkan aksinya".

Dengan demikian maka misi berdasarkan "teks" Yohanes 17:8 memiliki beberapa kesan penting yang berangkat dari pemahaman sebagaimana dikemukakan Tomata yakni "missio Dei". Yang mana memberi penekanan penting menganai pengutusan Allah 
sebagai pengutus, diamana Ia adalah sumber, inisiator, dinamisator, pelaksana, dan penggenap misi-Nya. Sebagai sumber misi, landasan bagi rencana Allah yang kekal ini berangka dari hati-Nya, dan Ia sendiri berinisiatif untuk melaksanakan misi-Nya, ditunjang oleh dinamika-Nya, (kekuatan/kuasa) guna melaksanakan dan mencapai misiNya tersebut (Tomatala, 2005).

Memahami term "mission Dei" secara mendalam dimana Allah sebagai pelaku utama dalam hal misi, tentunya Allah Bapa sanggup menjadikan siapa saja untuk mengerjakan misi-Nya. Dan di dalam Yesus Kristus sebagai "perantara" Allah dan manusia sesungguhnya menyadarkan orang pilihan-Nya untuk mengakui kedaulatan-Nya yang tidak terhingga dalam "mengintervensi" pelaksanaan misi bagi segala zaman (Lumintang, 2009). Kemudian, hal berikut yang diperoleh berdasarkan "teks", yakni ketika Yesus menyamakan posisi "status" para murid sebagai pribadi yang memiliki posisi sentral dalam pelaksanaan misi sebagaimana diri-Nya sendiri sebagai satu-satunya anak tunggal Bapa sebagai penerima pertama mandate misi itu.

Hari ini, dalam momen wisuda, juga pengutusan dan natal... kita dibimbing oleh teks ini untuk memahami bahawa hanya karena kasih Allah yang sejati maka Dia sendiri berinisiatif menjadi "penggerak" yang mengutus atau mengirim Anak-Nya yang tunggal dengan rela mengambil rupa manusia dalam pengertian inkarnasi yang akan menggenapi karya keselamatan bagi umat tebusan-Nya, termasuk bapak ibu saya, dan seluruh wisudawan. Maka kita sebagai umat yang terus menyakini, manyadari, dan mengalami kasih Allah ini. Maka tidak ada alasan untuk kita "memberhantikan" mandat Allah Bapa di dalam Yesus Kristus yaitu bersedia “dikirim” untuk menjadi pembaga-pembagi kabar keselamatan dimanapun kita berada.

\section{Misi Berdasarkan "Konteks" Dalam 17:18}

Dunia Palestina, atau sekitarnya pada zaman Yesus maupun zaman-zaman sebelumnya pada periode PL maupun periode intertestamental menjadi rujukan penting dan referensi manrik bagi kegiatan misi gereja mula-mula. Hal ini terjadi karena secara politik, sosial, budaya, ekonomi dan lainnya sangat mempengaruhi pola pelaksanaan misi itu sendiri. Maka disinilah diperlukan sebuah upaya penemuan akan benang merah secara misional dalam mewujudnyatakan misi secara "konteks" yang mana perlu mempertimbangkan beberapa aspek "konteks" dalam masing-masing tempat dimana misi dapat berimplikasi bagi gereja dan kekristenan missional saat ini (Webber, 1997). Beberapa dimensi yang masuk dalam kategori "konteks" ini tentunya sangat berpengaruh dalam melaksanakan tugas yang diberikan Yesus bagi para murid-Nya. Namun, berdasarkan "teks" pada bagian sebelumnya menjadi penghiburan tersendiri. Michaels (2010) menegaskan; "Hal ini terjadi karena para murid kemudian memahami bahwa Yesus "menggaransikan" mereka dengan kebesaran dan kedaulatan "Sang Bapa” sebagai 
inisiator misi yang tentunya juga akan menyertai mereka sebagai utusan-utusan dalam kaitannya dengan upaya meneruskan tugas misi pada zaman-zaman selanjutnya. Gambaran mengenai penyertaan Allah Bapa bagi para murid terkesan kuat ketika Yesus menekankan mengenai "sebagaimana Allah Bapa mengutusnya, maka sekarang Dia mengutus mereka".

Disadari bahwa upaya memahami misi berdasarkan "konteks" berdasarkan Yohanes 17:18 akan lebih menarik jika mengaitkannya dengan sekelumit latar belakang mengenai kondisi sosial, politik, ekonomi, budaya atau hal lain pada zaman gereja mulamula yang dapat dijadikan sebagai referensi penting untuk mengetahui dan melaksanakan misi itu sendiri. Dan itu berarti perlu mengetahui latar belakang kitab Injil Yohanes itu sendiri dan bahkan latar belakang dari seluruh PB yang berkaitan dengan "intertestamental". Namun pada kajian ini penulis membatasi pemahaman mengenai "konteks" dengan memperhatikan indikasi-indikasi atau keterangan yang menyangkut "konteks" sebagaimana tersurat atau tersirat dalam "teks" yang telah dikemukakan sebelumnya dan mengaitkannya dengan dunia latar PB secara umum saja sebagaimana kita ketahui.

Sebelumnya, perlu dipahami lebih dahulu pemahaman mengenai "konteks" dalam kaitannya dengan pemahaman mengenai misi yang berkorelasi dengan implikasi logis "kasih sejati dari Allah Bapa". Engen yang dikutip Lumintang (2009) menyatakan bahwa misi yang ber "Konteks" yaitu bagaimana orang Kristen memahami bahwa dirinya sendiri adalah pelaku misi yang terus mengupayakan pelaksanaan misi bagi orang-orang non Kristen dan masyarakat dunia yang membutuhkan garam dan terang Kristus melalui gereja sebagai obyek misi. Jika demikian maka secara tegas "konteks" misi menurut "teks" Yohanes 17:18 dapat dipahami dalam kata eij ton kosmoj ; eis ton kosmos. Secara spesifik, kata ton kosmon disini tidak menunjuk kepada sebuah daerah atau tempat tertentu dimana para murid akan diutus. Namun "ke dalam dunia" pada zaman itu tentunya tidak terlepas dengan tempat dimana para murid sehari-hari melaksanakan aktivitasnya, baik sebalum mereka menjadi pengikut Yesus, maupun setelah mereka menjadi pengikut Yesus sepenuhnya. Memperhatikan deskripsi Lumintang (Tomatala, 2005), penulis memahami kesan penting bahwa misi yang selalu menekankan mengenai "konteks" dalam pelaksnaanya, selalu terlihat dalam upaya kaum "Oikumenikal" dalam melakukan misi yang selalu cenderung dikaitkan dengan tindakan-tinkan yang menyentuh aspek atau dimensi sosial dan kemanusiaan serta sejenisnya. Maka di sinilah fungsi "teks" yang bersifat biblikal akan "sedikit" membatasi semangat oikumenekal yang cenderung mengabaikan makna "teks" dalam bermisi dan menjadikan "misi" menjadi tidak berfokus kepada "pewartaan akan Yesus sebagai Tuhan dan Juruselamat dan hanya menyentuh sisi kemanusiaan saja dalam realitasnya. 
Jika menghubungkan pemahaman "konteks" dimana seluruh "teks" PB menjadi sebuah realitas, sebagaimana dikemukakan pada bagian-bagian sebelumnya, maka hal "misi” sebagai implikasi logis "membagikan kasih sejati yang besumber dari Allah" yang dikaitkan dengan "konteks", hanya akan menjadi sebuah pembahasan "teori" yang lebih cenderung berkaitan dengan sisi soaial kemausiaan. Maka pada point inilah, perlu adanya sebuah upaya yang seimbang dari setiap pelaku misi agar selau menghubungkan kondisi "konteks" pada masa "teks" dan "konteks" pada masa sekarang ini dan di sini dan berfokus pada penekanan teks yang mana merujuk pada upaya "membagikan kasih sejati Allah Bapa" melalui Yesus Kristus sebagai Juruselamat satu-satunya. Memang benar bahwa sesungguhnya misi perlu bersentuhan dengan "dunia sekitar". Dimana seorang utusan berada dengan sikap terbuka terhadap segala kondisi sosial, politik, ekonomi, budaya dan lainnya. Di mana kita berada dan dengan sigap terus mengupayakan bagaimana "mendaratkan" konsep misi sebagaimana dimaksudkan Yesus. Namun tidak boleh mengabaikan penekanan dari teks Alkitab sebagai landasan berteologi dan bermisi yang sehat dan bertanggungjawab dalam zaman yang cenderung memahami segala sesuatu secara "relatif".

\section{Misi Berdasarkan "Komunitas" Dalam 17:18}

Mengawali pembahasan pada bagian ini, terlebih lebih dahulu dideskripsikan pengertian secara sederhana, mengenai komunitas. "Komunitas" dapat dipahami sebagai "sekelompok orang yang hidup dan saling berinteraksi pada suatu daerah atau tempat tertentu atau masyarakat atau peguyuban tertentu (Alwi, 2008). Rumusan ini terkandung beberapa kata operasional yang menarik untuk dianalisa. Penekanannya yaitu "adanya sekelompok orang yang saling berinteraksi pada sebuah daerah tertentu. Frasa "saling berinteraksi" mengandung sisi aktifitas dari seseorang kepada seseorang yang lain dengan tujuannya masing-masing yang ada dalam sebuah lokusi. Dan hal berikut yaitu "upaya interaksi yang dilakukan itu tergolong dalam satu komunitas masyarakat".

Pertanyaan yang muncul dari rumusan mengenai "komunitas" di sini yaitu: apa yang diinteraksikan dan siapakah yang berinteraksi? Maka pertanyaan ini mengantarkan kita pada rumusan penting ketika term "komunitas" dikaitkan dengan terminologi penting dalam tema kita dalam konteks misi. Mengomentari pemikiran tokoh misi Charles van Engen dalam mission on the Way, yang mengemukakan bahwa misi bukan hanya berbicara wilayah "teks" atau "konteks" melainkan juga wilayah "komunitas", Lumintang (2009) kemudian menjelaskan bahwa Starting point-nya adalah teks (Alkitab), yaitu proses refleksi mengenai pemahaman yang alkitabiah dan teologis mengenai misi Allah kepada pelaksanaan misi kepada suatu komunitas orang beriman dan kepada suatu konteks tempat dan waktu tertentu". 
Dalam sejarah perkembangannya, terdapat banyaknya "komunitas" yang turut memberi warna bagi eksistensi misi itu sendiri. Karena Injil yang merujuk pada pemahaman teks secara biblikal sebagaimana diwariskan oleh warisan orthodoxy (sebagai satu komunitas) dan kaum Oikumenikal (sebagai komunitas) yang lain dalam lingkup yang menglobal. Kedua kelompok atau komunitas besar ini secara sama-sama berkontribusi bagi eksistensi misi Kristiani dalam komunitas masyarakat dunia yang luas. Meskipun dalam pelaksanaannya, kaum Oikumenikal cenderung melepaskan "teks" dan dihakimi oleh kaum "Injili" dan mengutamakan "konteks" yang berfokus pada sisi kemanusiaan. Sedangkan kaum injili yang lebih menekankan aspek "teks" secara literal dan cenderung mengabaikan sisi kemausiaan. Fakta mengenai klaim dari kaum Injil dan kaum Oikumenikal, bahkan mungkin ada juga "komunitas yang lain, maka kemudian van Engen menegaskan bahwa aspek "komunitas" turut menjadi sebuah realitas yang tidak dapat dipisahkan ketika seseorang hendak membahas mengenai misi yang terus mengalami pergeseran dalam teks dan konteks.

Bagaimana dengan posisi setiap STT atau STAK maupun kelompok atau komunitas misi yang juga dapat dikategorikan sebagai salah satu "komunitas" yang eksis juga dalam bermisi? Sebutan PTT/AK dengan maksud menunjuk kepada STT atau STAK dan bahkan Institut dan Universitas sebagai lembaga pendidikan Tinggi yang kemudian melahirkan atau memberi kontribusi bagi eksistensi gereja pada berbagai denominasi yang secara legal merujuk pada sejumlah regulasi yang terkait dengan Kementerian Agama, dalam hal ini Direktur Jenderal Bimbingan Masyarakat Kristen. Sesungguhnya PTT/AK pun dapat digolongkan dalam term "komunitas" yang sudah, sedang, dan terus berkontribusi bagi misi. Posisi kurikulum dan pengajaran yang starting point nya selalu berciri Injili, Reformed atau apapun, sangat cukup untuk menunjukan posisi dari komunitas PTT/AK itu sendiri. Sesungguhnya "komunitas" PTT/AK yang sangat banyak jumlahnya saat ini, dimana saat ini cukup diakui karena berkontribusi besar bagi eksistensi misi di seluruh Indoinesia, baik di daerah-daerah perkotaan, dan terutama di daerah-daerah terpencil atau daerah pedalaman atau daerah pelosok nusantara.

"Komunitas" PTT/AK yang memiliki mistra strategis yakni berbagai denominasi gereja dan lembaga pendidikan dari jenjang Pendidikan Anak Usia Dini (PAUD) hingga Perguruan Tinggi bercorak keagamaan yang tersebar di seluruh Indonesia sangat potensial untuk memberi dampak yang besar bagi misi Kristus di Indonesia. Namun hal ini tidak berarti bahwa tidak memiliki kekurangan dalam pelaksanaannya. Namun komitmen dan dedikasi yang tinggi yang selalu diperlihatkan oleh setiap insan pembelajar maupun pelaku misi dalam "komunitas" PTT/AK, khususnya Institut, STT atau STAK sebagaimana diketahui bahwa saat ini cukup banyak yang berfokus pada hal mengenai "misi" dan jika didalami, selalu memiliki keunikan tersendiri. Keunikan yang penulis maksudkan selalu bertolak dari pokok pikiran dan didikan yang berasal dari para dosen 
sebagai pendidik yang tentunya memiliki kompetensi yang dianggap cukup, sehingga terus digalakkan oleh dosen kepada setiap anak didiknya yang berasal dari berbagai latar belakang suku dan budaya. Namun dijadikan satu "komunitas" misi melalui lembaga pendidikan yang kemudian terus berekspansi secara real hingga saat ini.

Menilik fakta sebagaimana dikemukakan di atas, maka tidaklah berlebihan bahwa setiap "komunitas" PTT/AK, yang selalu memberikan ruang untuk memahami "teks" yang digeluti pada masa perkuliahan bagi setiap mahasiswa. Kemudian disiniergikan dengan upaya memahami "konteks" pada masa praktek (PPL) yang tentunya terhitung sebagai beban satuan kredit semester yang perlu atau wajib dipenuhi. Sesungguhnya cukup menjadi modal dasar bagi setiap alumni atau lulusan PTT/AK yang baru diwisuda dan akan terlibat dalam sebuah gerakan misi. Menambah jumlah personil misi dalam komunitas misi tertentu yang menyadari bahwa kasih sejati Allah telah menjadi bagiannya melalui para pendiri dan pendidik, dan saat ini "kasih sejati" dari Allah Bapa yang sama siap diteruskan oleh para wisudawan yang akan diutus.

Pemahaman misi berdasarkan teks, konteks dan komunitas mengantarkan kita pada sebuah pemaknaan penting akan karya Allah yang sungguh menghibur dan menyenangkan. Mengutip pertanyaan pertama dalam Katekismus Heidelberg (End, 2004) dikatakan;

"apakah satu-satunya penghiburan saudara, baik pada masa hidup maupun pada waktu mati? Jawabannya adalah bahwa aku, dengan tubuh dan jiwaku, baik pada masa hidup maupun pada waktu mati (a), bukan milikku (b), melainkan milik Yesus Kristus, Juruselamatku yang setia (c). dengan darah-Nya yang tak ternilai harganya Dia telah melunasi seluruh hutan dosaku (d), dan melepaskan aku dari segala kuasa iblis (e), Dia juga memelihara aku (f), sehingga tidak sehelai rambutpun jatuh dari kepalaku di luar kehendak Bapa yang ada di sorga (g), bahkan segala sesuatu harus berguna untuk keselamatanku (h). Karena itu juga, oleh Roh-Nya yang Kudus, Dia memberiku kepastian mengenai hidup yang kekal (i), dan menjadikan aku sungguhsungguh rela dan siap untuk selanjutnya mengabdi kepada-Nya (j).

Pernyataan jawaban dari Katekismus Heidelberg menjadi rujukan penting bagi setiap orang Kristen, termasuk pelaku misi pada tataran teori atau akademis maupun pada tataran pelaksanaan yang menyadari akan anugerah keselamatan-Nya, juga dalam mempertahankan imannya sambil memikirkan berbagai upaya melaksanakan misi Allah yang sangat mengasihi umat tebusan-Nya. Dikatakan sebagai penghiburan karena tidak mudah untuk menjadi utusan pada zaman dimana segala sesuatu bergerak begitu cepat dan membutuhkan daya tahan yang tangguh, juga daya tanggap yang tepat dan bijaksana. Perkembangan ilmu pengetahuan dan teknologi yang begitu cepat membutuhkan kesigapan yang lebih untuk dapat berbuat sesuatu pada zaman dimana kita berada dan 
patut menjadi duta-duta misi Allah untuk menjadi penerus pembagi kasih sejati Allah yang telah kita dapatkan hanya karena anugerah-Nya semata.

Dalam konteks PTT/AK saat ini, bahwa sesungguhnya apa yang dilakukan adalah sebuah fakta akan kasih Allah yang terus menjadi bagian dari keluarga besar atau komunitas PTT/AK dimana pun berada. Di mana setiap saat dapat mengadakan wisuda untuk jenjang sarjana maupun jenjang Pascasarjana (S2/S3) yang masih ada dan terus dipakai Tuhan menjadi alat "pembagi kasih". Maka bagi semua pelaku misi pada PTT/AK yang setiap saat menyaksikan momen wisuda atau pengutusan patut berbangga karena pada momen itu sekaligus menujukan bahwa kasih Allah Bapa masih ada bagi masingmasing PTT/AK. Dan, kasih Allah ini kemudian menjadi penggerak dari segala hal yang dilakukan pada setiap unsur yang berada dalam konteks pada PTT/AK. Banyak PTT/AK yang saat ini eksis, tentu pernah mengalami pergumulan-pergumulan atau masa-masa tertentu yang dianggap menyulitkan. Maka, tidaklah berlebihan jika PTT/AK yang diketahui masih ada hingga saat ini hanya karena kasih Allah semata. Semua alumni atau lulusan PTT/AK yang telah diwisuda pada jenjang tertentu, kiranya (sebaiknya) menyadari akan posisinya sebagai duta-duta Kristus yang telah menerima bagian dari kasih Allah itu melalui para pengelola, baik itu dari pihak gereja, Yayasan, pihak sponsor atau donatur, dan juga pihak pengelola di kampus, mulai dari Pimpinan sampai kepada semua staf pendidik dan kependidikan yang telah menjadi saluran kasih Allah Bapa untuk kalian dapat menjadi taruna-taruna yang siap diutus dalam ladang Tuhan di seluruh tempat diaman Tuhan menghendaki seorang lulusan PTT/AK berada.

\section{Kesimpulan}

Berangkat dari upaya memahami misi berdasarkan teks, konteks dan komunitas berdasarkan Yohanes pasal 17:18 maka sampailah kepada sebuah kesimpulan yang juga menjadi sebuah refleksi penting bagi keunikan dari penelitian ini. Kasih sejati Allah bukan hanya sebuah konsep, atau sebuah angan-angan belaka. Sebab Allah sendiri berinisiatif untuk mengutus anak-Nya yang Tunggal yaitu Yesus Kristus untuk menebus manusia berdosa yang dikasihi-Nya yang dapat dipahami oleh seorang pelaku misi dalam momen apapun. Kata "kasih sejati" tidak ada secara harfiah dalam teks Injil Yohanes pasal 17:18, namun dijadikan sebuah lema penting yang menajadi landasan tema atau judul bagi artikel ini. Namun merujuk pada pemaknaan "teks" yang dikaitkan dengan konteks kitab secara keseluruhan, maka tidak terbantahkan bahwa semua yang dilakukan Yesus bagi para murid tidak terlepas dari peran Allah Bapa sebagai inisiator utama dalam segala hal yang didasari atas kasih-Nya. Bahwa kasih Allah sangat penting dan mendasri segala keputusan dan rancangan-Nya bagi seluruh alam semesta dan termasuk manusia yang Ia ciptakan seturut dan segambar dengan rupa-Nya dan diberikan mandat untuk bertanggungjawab atas segala ciptaan-Nya. 
Sesuai dengan judul artikel ini, yang secara "teks" dapat dipahami bahwa kasih Allah memungkinkan Dia mengutus Anak-Nya yang tunggal untuk menggenapi misiNya. Dan kemudian dalam anugerah-Nya; Sang Anak meneruskan mandat Allah Bapa itu kepada para murid untuk menjadi satu "komunitas" pembagi kasih Allah Bapa. Tugas inilah yang kemudian diteruskan oleh generasi saat ini sebagai penerima mandat misi itu. Jangan takut, sebab misi yang dikerjakan adalah misi Allah Bapa. Yang mana, dalam penekanan-Nya, Yesus menggaransikan bahwa misi yang dikerjakan oleh setiap pelaku misi adalah misi kepunyaannya dari Dia yang adalah pemilik alam semesta, juga pemilik hidup pelaku misi itu sendiri dan semua orang Kristen yang mencitai misi, sebab hanya Dia-lah Sumber Kasih Sejati: Yang mengutus Anak-Nya yang Tunggal, yang mengutus para murid, dan juga mengutus setiap lulusan atau alumni PTTAK sebagai satu komunitas untuk kemuliaan nama-Nya "Ex Opere Operato - Soli Deo Gloria".

\section{Daftar Rujukan}

Alwi, H. (2008). Kamus Besar Bahasa Indonesia Edisi Ketiga, Cetakan Kelima. Jakarta: Balai Pustaka, Pusat Bahasa Departemen Pendidikan Nasional.

Balz, H., \& Schneider, G. (1994a). Exegetical Dictionary of the New Testament Volume-2. Grand Rapids Michigan: William B, Eerdmans Publishing Company.

Balz, H., \& Schneider, G. (1994b). Exsegetical Dictionary of The New Testament, Volume-1. Michigan: William B. Eerdmans Publishing Company.

Calvin, J. (2001). Genesis, (Crossway Clasic Commentaries). Wheaton, Illinois: Crossway/Good News Publishers.

Colins, G. O. (1996). Kamus Teologi. Yogyakarta: Kanisius.

Creswell, J. W. (2016). Research Design, Pendekatan Metode Kualitatif, Kuantitatif, dan Campuran. Yogyakarta: PUSTAKA PELAJAR.

End, T. van den. (2004). Katekismus Heidelberg, Dalam Enam Belas Dokumen Dasar Calvinisme. Jakarta: BPK Gunung Mulia.

Ferguson, D. S. (1986). Biblical Hermeneutics: An Introduction. Atalanta: John Knox Press.

Hartati, N. (2017). Statistika untuk Analisis Data Penelitian. Bandung: Pustaka SETIA.

Httpp://forlap.ristekdikti.go.id/perguruantinggi/search/380. (2020). https://forlap.ristekdikti.go.id/perguruantinggi/search/380.

Keener, C. S. (2003). The Gospel of John, A Commentary Volume One. Michigan: Baker Academic.

Lumintang, S. I. (2009). Misiologia Kontemporer, Menuju Rekonstruksi Misiologia yang Seutuhnya. Batu, Malang: Departemen Multi-Media YPPII.

Michaels, J. R. (2010). The New International Commentary on the New Testamen The Gospel of John. Grand, Rapids Michigan: WM. B. Eerdmans Publishing Company.

Pandensolang, W. (2010). Gramatika dan sintaksis bahasa Yunani dalam Perjanjian Baru. Jakarta: YAI Press.

Pohan, E., \& Setiawidi, A. (2015). Bahasa Ibrani untuk Pemula. Jakarta: BPK Gunung Mulia.

Ridderbos, H. N. (2012). Injil Yohanes, Suatu Tafsiran Teologis. Surabaya.

Rogers Jr, L., C., \& Rogers III, C. L. (1998). The New Linguistic and Exegetical Key to 
the Greek New Testament. Grand Rapids, Michigan: Zondervan Publishing House.

Schafer, R. (n.d.). Belajar Bahasa Yunani Koine, Panduan Memahami dan

Menerjemahkan Teks Perjanjian Baru.

Sugiyono. (2017). Metode Penelitian Kebijakan, Pendekatan Kuantitatif, Kualitatif, Kombinasi, $R \& D$ dan Penelitian Evaluasi. Bandung: ALFABETA.

Sutanto, H. (2004a). Perjanjian Baru Interlinear Yunani-Indonesia dan Konkordansi

Perjanjian Baru (PIBK) Jilid-1. Jakarta: Lembaga Alkitab Indonesia.

Sutanto, H. (2004b). Perjanjian Baru Interlinear Yunani-Indonesia dan Konkordansi

Perjanjian Baru (PIBK) Jilid-2. Jakarta: Lembaga Alkitab Indonesia.

Tim Penterjemah \& Penyusun. (2002). Tim Penerjemah dan Penyusun, Perjanjian Baru Yunani-Indonesia (Edisi Ke-2). Jakarta: Lembaga Alkitab Indonesia.

Timotius, K. H. (2017). Pengantar Metodologi Penelitian, Pendekatan Manajemen Pengetahuan untuk Perkembangan Pengetahuan. Yogyakarta: Penerbit ANDI.

Tomatala, Y. (2005). Teologi Misi, Pengantar Misiologi: Suatu Dogmatika Alkitabiah Tentang Misi Penginjilan dan Pertumbuhan Gereja. Jakarta: YT Leadership Foundation.

Webber, R. E. (1997). Journey to Jesus, the Worship Evangelism and Nature Mission of the Church. Nashvile: Abingdon Press.

Wenham, G. J., \& Carson, D. A. (2010). 21st-Century Edition, New Bible Commentary. Nottingham: Inter-Versity Press.

Wright, C. J. H. (2013). Misi Umat Allah. Jakarta: Literatur Perkantas.

Yuwono, U. (2005). Pesona Bahasa. Jakarta: Gramedia Pustaka Utama. 